\title{
A ERA DO CAPITAL: LIBERALISMO E IMIGRAÇÃO ITALIANA NA PROVÍNCIA DO ESPÍRITO SANTO DURANTE A SEGUNDA METADE DO SÉCULO
}

\author{
Victor Silva Salaroli do Nascimento ${ }^{1}$ \\ Mateus Augusto Almeida Martins ${ }^{2}$ \\ Mellina de Fátima Neres Curty ${ }^{3}$
}

\begin{abstract}
Resumo: O artigo discute a influência do liberalismo na expansão do processo de imigração italiana para a Província do Espírito Santo, durante a segunda metade do século XIX. À luz desta discussão, é examinado o jornal O Cachoeirano (1877-1923), principal veículo de comunicação do sul da Província em meados do século XIX, além do relato do Cônsul italiano Carlo Nagar, que, no final do século XIX (1895), teceu severas críticas ao então Estado do Espírito Santo, levando o governo italiano a proibir este processo migratório. Assim, de modo geral, o artigo explicita que, em países como o Brasil, e, mais precisamente, a então Província do Espírito Santo, as novas relações de produção, o eminente fim da escravidão, a falta de indústrias e de mão de obra contribuíram de forma expressiva para a expansão do número de imigrantes europeus que entraram em território capixaba.
\end{abstract}

Palavras-chave: Imigração italiana; Espírito Santo; História.

\footnotetext{
${ }^{1}$ História/Faculdade de Filosofia Ciências e Letras de AlegrelES, Brasil. E-mail: victorsalaroli26@gmail.com.

2 História/Faculdade de Filosofia Ciências e Letras de AlegrelES, Brasil. E-mail: m_ateusaugusto@hotmail.com.

${ }^{3}$ História/Faculdade de Filosofia Ciências e Letras de AlegrelES, Brasil. E-mail: mell.curty@hotmail.com.
} 